\title{
Social responsibility disclosure of Indonesian Islamic Index Company
}

\author{
Antin Okfitasari $^{1}$, Ety Meikhati ${ }^{2}$, Novi Widyawati ${ }^{3}$ \\ \{antin_okfitasari@stmikdb.ac.id ${ }^{1}$ \} \\ ${ }^{1}$ Department of Informatika Management, Duta Bangsa University, Indonesia \\ ${ }^{2}$ Department of Informatika Management, Duta Bangsa University, Indonesia \\ ${ }^{3}$ Management Magister Student, Sebelas Maret University, Indonesia
}

\begin{abstract}
This research is aimed to analyze the disclosure level of Social Reporting in companies listed in Jakarta Islamic Index (JII) using ISR index. This research is descriptive research, that is research which try to describe and interpret result of ISR index score based on six criteria: Funding and Investment, Products and Services, Employee, Society, Environment and Corporate Governance. The population of this study are all companies listed in JII period 2014-2016. The sampling method used in this research is purposive sampling method. The result of research shows that the most disclosure on the six ISR index criteria conducted by 21 companies listing in JII is environmental criteria. This proves that there is an awareness of the environmental social responsibility of companies listing in JII. Overall, the average disclosure of the ISR index on $21 \mathrm{JII}$ firms has not been good, only $47.80 \%$. This indicates that there are still many ISR index items that have not been fully disclosed. The results also show a tendency to increase the ISR index. This condition proves the increase of corporate awareness of the obligation of social responsibility according to sharia. This condition proves the increase of corporate awareness of the obligation of social responsibility according to sharia.
\end{abstract}

Keywords: Social Reporting, Islamic Company, social responsibility disclosure.

\section{Introduction}

In line with the development of sharia economy in the world, the concept of Corporate Social Responsibility (CSR) that shall be in accordance with Islamic values in accordance with Qur'an and Sunna of the Prophet Muhammad PBUH has also flourished [1][2][3]. CSR according to Islamic teaching promotes falah (justice) and ukhuwah (brotherhood), so that sharia-compliant companies can accommodate the needs of each party and the interest of the public [4][5]. For companies engaged in the field of sharia, they necessarily require guidelines in preparing annual reports by presenting the implementation of social responsibility in accordance with sharia in such reports. These guidelines are known as Islamic Social Reporting (ISR). [6] developed the ISR index which had been initiated by [7] by adding in the index of ISR disclosure with corporate governance. 
Researches related to ISR have been conducted in Islamic Financial Institution (IFI), mainly in sharia banking sector. This research done by [8], [9], [3], [10], [11]. Other studies have linked the characteristics of banks or firms listed in Islamic capital markets with ISRs, such as researches conducted by [6], [12], [13], [14]. Researches on the disclosure of ISR in companies listed in sharia capital market have also been conducted. [15] examined ISR disclosures in large corporations other than in the finance industry approved by sharia authorities listed in Bursa Malaysia. The result proved that the companies' ISR disclosures in Bursa Malaysia was indicated to be minimal, marked by a minimum disclosure of sharia related disclosure items.

This study aims to analyze the disclosure of ISR by companies listed in Jakarta Islamic Index (JII). The latter is one of the sharia capital market products in Indonesia Stock Exchange, where the listed companies' shares are considered eligible by the National Sharia Council (DSN) of the Indonesian Ulama Council. This research is a replication of research conducted by [15], but different in the object research. Based on the above explanations, this study formulates the research problem as to how the disclosure of Social Responsibility with ISR index in companies listed in the Jakarta Islamic Indeks.

\section{Literature Review}

\subsection{Islamic social reporting}

In Islam, the business opeartional can never be alone face from the rest social responsibility and rights all stakeholder [16]. [14] said if concept Corporate Social Responsibility not only in the conventional economics, but for sharia economics.Increasing implementation of CSR from the perspective of Islam triggers the emergence of standards in connection with the reporting of performance of a sharia-based company in the form of Islamic Social Reporting (ISR). The ISR Index was born on the basis of compilation of standard CSR items based on AAOIFI (Accounting and Auditing Organization for Islamic Financial Institutions). ISR index was firstly promoted by [7] and further developed by subsequent researchers extensively such as by [6] in Malaysia and other researchers. According to [7], there are still many limitations in the conventional social reporting and proposing a conceptual framework of ISR based on sharia provisions. [17] further explains that the improvement of corporate governance in islamic financial system is absolutely necessary, as the public have the right to know on various information about an organization's activities. ISR requires a company to disclose their performance reporting to prove that the company has fulfilled its duties and obligations according to sharia and to ensure that its operation is not contrary to the concept of sharia.

\subsection{Review on previous research}

Researches on ISR disclosure in sharia banks and companies listed in sharia capital market have been conducted by several researchers. Othman and Thani's studies [15] measured ISR levels of 100 companies other than in financial industry listed in Bursa Malaysia approved by sharia authorities, through multiyear annual reports of 2004- 
2006. Using 43 items of disclosure index and categorized into 6 themes, namely Funding and Investment; Products/Services; Employees; Communities; Environment, and Corporate Governance. The results showed that the level of ISR disclosures were minimal, so that in overall there have not been significant ISR disclosure.

This research is a replication of [15] research, however, the difference relates to the samples selected. [15] selected samples of companies listed in Bursa Malaysia approved by the relevant sharia authorities, while this study takes the samples of companies listed in JII. On the other hand, this study selects the samples of companies listed in JII using multi year of annual reports with trend analysis to analyze the ISR disclosure rate.

\section{Research Method}

\subsection{Population and Sample}

This study uses all companies listed in JII as population that meet the following criteria (purposive sampling):

a. Listed in the Jakarta Islamic Index in the period of $2014-2016$;

b. The company publishes annual report in the period of 2014-2016.

Based on the above criteria, the number of samples amounting to 21 companies listed in JII are obtained.

\subsection{Data analysis}

The data used in this study is secondary data in the form of companies' annual reports selected as the samples. The method used in this study is content analysis, which aims to identify the criteria of the index of ISR. The ISR Index model follows that of according to the research of [15]. The ISR Index is divided into six categories: Funding and Investment, Products and Services, Employees, Society, Environment, and Corporate Governance.

Content analysis is performed by reading the annual reportsof the samples and giving the score value. The scoring method utilized in this study is similar to that of [15]. Content analysis was performed on 43 ISR index items, where scoring was given not based on how often the number of occurrences of each item was disclosed in an annual report.If at least an ISR index disclosure item is disclosed once, the relevant item is considered to exist. Assessment is done by scoring from 0-1, where:

- Value 0 is applied if there is absolutely no disclosure regarding the item;

- Value 1 is applied if disclosure is made, at least once disclosure.

Assessment of index items is then collected, identified, and analyzed by summing up the overall score annually, so the pattern of ISR disclosure every year is known. Calculation of the ISR index is formulated as follows:

$$
\text { CSR }=\text { Number of items disclosed by the company }
$$

The number of expected items is disclosed 
In addition to summing up the scores obtained per year for all companies within the samples as a whole, the score of each sample company and each category of ISR index are summed up. This method is done to determine which disclosure categories are mostly disclosed by the companies and which companies perform the highest ISR disclosures. Based on the results of this score, a review is further conducted on how the implementation of ISR in companies listed in JII.

\section{Result and Discussion}

Based on the content analysis presented in table 1, it can be seen all categories of ISR disclosure items. Overall, table 1 show that the highest disclosed category of JII is the environmental category. The company that discloses the highest environmental category in the period of 2014-2016 is PT Astra Agro Lestari Tbk, with an average score of $31,75 \%$. The lowest environmental disclosure was conducted by PT Bumi Serpong Indah Tbk with an average score of $14,29 \%$. Of the seven environmental indicators, there are consistent indicators that are disclosed each year, i.e., environmental conservation, environmental auditing/independent verification/government statements, and environmental/policy management system.

Since the highest disclosed category in this study is the environmental category with an average score of $67.80 \%$, this shows the high awareness of the companies listed in JII towards the importance of environment. This awareness of the environment is evidenced by the increase of year-to-year Program for Pollution Control, Evaluation and Rating (PROPER) award given tothe companies listed in JII [14]. PROPER is a corporate performance rating program organized by the Ministry of Environment to encourage compliance of the companies with environmental management through information instruments. The awarding of PROPER to a company that has an awareness of the importance of the environment as disclosed in its annual report provides an evidence of such company's concern and responsibility for the surrounding environment. Awareness of the importance of the environment is also due to the obligation ofthose industrial companies to maintain the surrounding environment in accordance with Law No. 5 of 1984 [18] regarding Industry, especially article 21. Such Article 21 imposes an obligation to the industrial companies to maintainthe balance and sustainability of natural resources used in the process of industry. In addition, there is an obligation to prevent the damage and pollution of the environment as the results of business and industrial processes undertaken by the companies. Furthermore, in article 27, it is stipulated that a fine shall be given as a result of an intentional/unintentional action for violation of article 21 . This means, the company of JII have high environmental impacts. This finding is line with islamic principles, where as khalifah, humans as guardians of the earth must guard and care it from damage.

Through the trend analysis, the results of this study provide empirical evidence that companies listed in JII have increased in the ISR disclosure in their annual report. This condition proves that the company which in its operation does not contradict the concept of sharia and its shares listing in sharia capital market, the better in disclosing the implementation and reporting of its social obligations. The ISR disclosure of 2015 to 2016 only increased by $22.11 \%$ lower than the 2014 to 2015 increase. According to 
Table 1, in general, ISR index score for each category shows inconsistency during 2014-2016, except category of Products and Services as well as Community, which are increasing year by year. The minimum category disclosed by companies listed in JII is the category of corporate governance. Of the five indicators of corporate governance category, only the indicator of anti-corruption policies is disclosed. This condition is understandable considering that the companies listed in JII are not companies that operate purely based on the concept of sharia.

Category of Products and Services occupies the second rank of disclosure conducted by companies listed in JII, with an average score of $60.32 \%$. This score indicates the awareness of the company listed in JII with the importance of disclosure of products and services offered. Almost all indicators of this category do not have consistency disclosure annually, unless the halal status of the product increases from 2014-2016. The Government has affirmed through Law No. 33 of 2014 on Halal Product Guarantees [19], that all products entered, circulated and traded in the territory of Indonesia must be halal certified. The highest disclosure of this category was conducted by PT Unilever Indonesia Tbk with an average score of 30,56\%. This is because PT Unilever Indonesia Tbk during 2015 and 2016 is the only company that discloses the four indicators of product and service category. The lowest disclosure of this category, was conducted with an average score of 2,78\% by PT Bumi Serpong Indah Tbk.

From the category of Funding and Invesment, obtained the average value of disclosure from 2014-2016 amounted to $27.78 \%$. This figure shows the low disclosure of this category. From table 1, there is consistency of VAS reporting every year that is $80,95 \%$. This shows that from the selected sample, 17 of the same companies reveal VAS indicators every year in their annual report. However, the disclosure of the VAS is different from the VAS referred to by [20], where according to [20] the VAS is a complementary report of the income statement of the company so as to provide relevant information to stakeholders. Another consistency is the lack of disclosure of riba (usury) and zakat. this is consistent with the findings of [15]. Zakah payments and the avoidance of usury are examples of Islam emphasizing the principle of justice [1]. As explained earlier, this is because companies listed in JII are not companies engaged in sharia, where the concept of sharia becomes the basis of the company's operations. The CVBS disclosure is also not done, as a complementary balance sheet presented in the annual report. The balance sheet is presented using historical cost, so it should be necessary to provide relevant information for Muslim stake holders to present CVBS reports [20]. When viewed from the average disclosure of the Funding and Investment category during 2014-2016, the highest disclosure is done by PT Lippo Karawaci Tbk with average score of $16.67 \%$. The lowest disclosure score is done by PT Astra International Tbk with a score of zero percent.

Community category based on table 1 , has an average disclosure value of $55.70 \%$. This score indicates a high awareness of the companies listing in JII related to the mutual sharing and lighten the burden of society. This is in accordance with the statement of [7][2], which explains that the basic concept of this category is the ummah, amanah and adl. Thus a high score indicates the company's concern for community togetherness, public trust and the realization of justice for the community around the company. Of the 11 indicators of this category, none of the companies listed in JII disclose waqaf and qardhassan indicators. These 
results are in line with findings by [12] and [21] who found that this indicator is rarely revealed by Shari'ah Compliant Companies in Bursa Malaysia. Yet through these two indicators, the needs of the ummah (community) can be realized [7]. The highest disclosure of this theme was conducted by PT Vale Indonesia Tbk with an average score of $24.24 \%$, and the lowest disclosure was conducted by PT Akr Corporindo Tbk, PT Siloam International Hospital Tbk and PT Summarecon Agung Tbk with an average score of $13.13 \%$.

Table 1: The ISR Score of Disclosure According to Individual Items and Categories

\begin{tabular}{|c|c|c|c|c|}
\hline No & Items of disclosure & $\begin{array}{c}2014 \\
\%\end{array}$ & $\begin{array}{c}2015 \\
\%\end{array}$ & $\begin{array}{c}2016 \\
\%\end{array}$ \\
\hline A & Finance And Investment Theme & 26.98 & 28.57 & 27.78 \\
\hline 1 & Riba Activities & 0.00 & 0.00 & 0.00 \\
\hline 2 & Gharar & 52.38 & 57.14 & 61.9 \\
\hline 3 & Zakat: method used/amount/beneficiaries & 0.00 & 0.00 & 0.00 \\
\hline 4 & Policy on Late Repayments and Insolvent Clients/Bad Debts Written-off & 28.57 & 33.33 & 23.81 \\
\hline 5 & Current Value Balance Sheet (CVBS) & 0.00 & 0.00 & 0.00 \\
\hline 6 & Value Added Statement (VAS) & 80.95 & 80.95 & 80.95 \\
\hline $\mathbf{B}$ & Products And Service Theme & 58.33 & 59.52 & 63.10 \\
\hline 7 & Green product & 80.95 & 80.95 & 76.19 \\
\hline 8 & Halal status of the product & 4.76 & 14.29 & 19.05 \\
\hline 9 & Product safety and quality & 76.19 & 80.95 & 80.95 \\
\hline 10 & $\begin{array}{l}\text { Customer complaints/incidents of non-compliance with regulation and voluntary } \\
\text { codes (if any) }\end{array}$ & 71.43 & 61.90 & 76.19 \\
\hline $\mathbf{C}$ & Employees Theme & 49.05 & 54.29 & 51.90 \\
\hline 11 & Nature of work: working hours/holidays/other benefits & 23.81 & 33.33 & 42.86 \\
\hline 12 & Education and Training/Human Capital Development & 100.00 & 100.00 & 100.00 \\
\hline 13 & Equal Opportunities & 80.95 & 80.95 & 71.43 \\
\hline 14 & Employee involvement & 76.19 & 76.19 & 80.95 \\
\hline 15 & Health and safety & 100.00 & 100.00 & 100.00 \\
\hline 16 & Working environment & 100.00 & 100.00 & 90.48 \\
\hline 17 & $\begin{array}{l}\text { Employment of other Special-interest-group (i.e. Handicapped, ex-convicts, former } \\
\text { drug-addicts) }\end{array}$ & 0.00 & 4.76 & 4.76 \\
\hline 18 & $\begin{array}{l}\text { Higher echelons in the company perform the congregational prayers with lower and } \\
\text { middle level managers. }\end{array}$ & 0.00 & 0.00 & 0.00 \\
\hline 19 & $\begin{array}{l}\text { Muslim employees are allowed to perform their obligatory prayers during specific } \\
\text { times and fasting during Ramadhan on their working day. }\end{array}$ & 4.76 & 23.81 & 14.29 \\
\hline 20 & Proper place of worship for the employees & 4.76 & 23.81 & 14.29 \\
\hline D & Society Theme & 44.59 & $\mathbf{5 8 . 4 4}$ & 64.07 \\
\hline 21 & Saddaqa/ donation & 19.05 & 33.33 & 80.95 \\
\hline 22 & Waqf & 0.00 & 0.00 & 0.00 \\
\hline 23 & Qardhassan & 0.00 & 0.00 & 0.00 \\
\hline 24 & Employee Volunteerism & 90.48 & 90.48 & 90.48 \\
\hline 25 & Education: School Adoption Scheme/Scholarships & 33.33 & 95.24 & 85.71 \\
\hline 26 & Graduate employment & 23.81 & 42.86 & 57.14 \\
\hline 27 & Youth development & 14.29 & 52.38 & 57.14 \\
\hline 28 & Underprivileged Community & 95.24 & 66.67 & 61.90 \\
\hline 29 & Children care & 28.57 & 61.90 & 71.43 \\
\hline 30 & Charities/Gifts/Social activities & 90.48 & 100.00 & 100.00 \\
\hline 31 & Sponsoring public health/recreational project/sports/cultural events & 95.24 & 100.00 & 100.00 \\
\hline $\mathbf{E}$ & Environment Theme & 65.99 & 72.11 & 65.31 \\
\hline 32 & Conservation of environment & 85.71 & 85.71 & 85.71 \\
\hline 33 & Endangered wildlife & 4.76 & 9.52 & 4.76 \\
\hline 34 & Environmental Pollution & 66.67 & 76.19 & 61.90 \\
\hline 35 & Environmental Education & 33.33 & 71.43 & 33.33 \\
\hline
\end{tabular}


36 Environmental Products/Process related

37 Environmental Audit/Independent Verification Statement

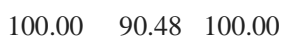

38 Environmental Management System/Policy

39 Shariah compliance status

40 Ownership structure: Number of muslim shareholders and its shareholdings 0.00

41 BOD structure-muslim vs non-muslim members goods/price manipulation/fraudulent

43 Anti-corruption policies

\begin{tabular}{llll} 
& 52.38 & 33.33 & 42.86 \\
\hline TOTAL & $\mathbf{4 3 . 9 6}$ & $\mathbf{4 9 . 6 1}$ & $\mathbf{4 9 . 8 3}$
\end{tabular}

The Employee category has an average rating of $51.74 \%$. This value proves the existence of awareness of the company associated with concern for its employees. No company listed on JII discloses the higher Echelon at the company performing congregational prayers with lower and middle level managers. This finding is the same as [15]. The indicators disclosed by all companies listed in JII are education and training / human resources development and occupational health and safety. The Company is required to disclose both of these indicators based on Law no. 1 of 1970 on Occupational Safety Law No. 23 of 1992 on Health and Law no. 13 of 2003 on Manpower. There are sanctions for companies that do not want to comply with these three packages of rules. The most disclosure of this category was conducted with PT Telekomunikasi Indonesia Tbk with an average score of $24.44 \%$, while the lowest average was revealed by PT Summarecon Agung of $11.11 \%$.

The category of Corporate Governance is the lowest theme revealed by companies listing in JII with an average score of $8.57 \%$. This condition shows the weakness of corporate governance of the JII company according to the concept of sharia. The highest average score of each company amounted to $6.67 \%$, ie disclosure of anti-corruption policies disclosed by 6 companies listing in JII.

In aggregate, the average disclosure value of ISR companies listed in JII is $47.80 \%$. This shows the ISR disclosure at moderate level. Companies listed in JII have not yet disclosed the full ISR index items. For all period of this research, it is showed that items related to sharia law are not met by all companies listed in JII. Such disclosures include usury, zakat, CVBS, higher echelon in the company performing congregational prayers with lower and middle level managers, Waqaf, Qordhassan. The three indicators of corporate governance criteria relating to the concept of sharia are also not disclosed for the three year period, namely, the status of sharia compliance, the ownership structure between Muslim and non-Muslim, and forbidden activities. This finding is in line with the findings of [12], [21] and [15] which found that there was still a low disclosure of ISR on Shari'ah Compliant Companies in Bursa Malaysia in connection with the principles and values of Islam. Companies listed in JII are understandably not fully operational companies based on the concept of sharia. However, companies whose shares have passed the selection of the Financial Services Authority and the Indonesia Stock Exchange to be registered in the sharia capital market and their operations are not contradictory to the concept of sharia, the indicators related to Islamic principles and values are not disclosed. Of all ISR indicators, only indicators of Education and Training / Human Resource Development and Occupational Health and Safety indicators are fully disclosed by all companies listed in JII during 2014-2016. Viewed from companies listed in JII, the overall ISR disclosure is mostly performed by PT. Telekomunikasi Indonesia Tbk with an average score $78,81 \%$ while the lowest ISR disclosure is perfomed by PT. Summarecon Agung Tbk with an average score of $51,68 \%$. 
In accordance with the theory of legitimation, the company will conduct ISR activities due to social, economic and political pressures from outside the company, so that the company will meet such demands by doing what the community want and what is required by the rules [22]. The increase of ISR index in companies listed in $\mathrm{JII}$ is caused by the pressure from the government through various regulations. This is consistent with Mohamed Zain's (2004) statement in [6], stating that government policy is one of the main factors to encourage companies to produce high-level ISR disclosures. Stakeholder theory states that ISR activity is an effort to accommodate stakeholders' needs and wants, so that the company in the long run can improve its profitability [3] and company's image [10]. In Indonesia with the majority of muslim population, the company shall consider the main stakeholders which provide good support for the company's business activities. Disclosure of ISR is one way to manage good relationships between companies and stakeholders [8], [10],[16]. Muslim stakeholders will certainly be more comfortable to invest in shares of companies that do not violate the concept of sharia. Because the objectives of Islamic social and economic system are based on human well-being and the life of Tayyibah (good life), both of which emphasize ukhuwah (brotherhood) and adl (justice) based on piety towards God SWT [23]. Thus, a clear, complete and comprehensive ISR indicators shall be required to accommodate the needs of muslim stakeholders in Indonesia in order to avoid multi-interpretation in determining the ISR disclosures.

\section{Conclusion}

This study aims to find out the disclosure of ISR in annual reports of companies listed in JII. Based on description of analysis and content analysis, the overall average of ISR disclosure rate is $47.80 \%$. Companies listed in JII have not disclosed the full items of the ISR index. Even items related to sharia concepts such as Zakat, Riba, Waqaf, Qordhassan, higher echelon in the company performing congregational prayers with lower and middle level managers, sharia-related corporate governance are not disclosed by all companies listed in JII.

Indicators of Education and Training/Human Resource Development and Occupational Health and Safety indicators are fully disclosed by all companies listed in JII in order to meetthe obligations required by relevant laws. The environmental category is the most commonly disclosed category by companies listed in JII. This is due to high awareness of such companies listed in JII concerning the sustainability of natural resources used in the process of industry. The role of government by issuing the relevant laws also support this high level of disclosure.

The limitation of this research is due to the measurement of the ISR index is based on the interpretation of the researcher, requiring some subjectivity in the absence of complete, clear, and comprehensiveISR standards. In addition, the source of ISR index measurement is merely based on the annual reports. Future research shall pay attention to the media involvement as a measure of ISR disclosure. 


\section{References}

[1] Maali B, Casson P, and Napier C 2006 Social reporting by Islamic banks, Abacus. 42 266-289

[2] Dusuki AW 2008 What Does Islam Say about Corporate Social Responsibility?, Rev. Islam. Econ.12 5-28

[3] Darus F, Mad S, and Yusoff H 2014 The Importance of Ownership Monitoring and Firm Resources on Corporate Social Responsibility (CSR) of Financial Institutions, Procedia - Soc. Behav. Sci. 145 173-180

[4] Hassan A, Salma H, and Abdul B 2009 Corporate social responsibility of Islamic financial institutions and businesses, 25 177-188

[5] Hamidu AA, Haron H Md, and Amran A 2015 Corporate Social Responsibility: A Review on Definitions, Core Characteristics and Theoretical Perspectives, Mediter Journal Social Sciences

[6] Othman R, Thani AM, and Ghani EK 2009 Determinants Of Islamic Social Reporting Among Top Shariah -Approved Companies In Bursa Malaysia, Res. J. Int. Stud. 12 4-20

[7] Haniffa R 2002 Social Reporting Disclosure-An Islamic Perspective, Indones. Manag. Accounting Research. 1 128-146

[8] Darus F, Mad S, and Nejati M 2015 Ethical and Social Responsibility of Financial Institutions: Influence of Internal and External Pressure, Procedia Econ. Financ. 28, 183-189, 2015.

[9] Farook S 2007 On Corporate Social Responsibility Of, Islam. Econ. Stud. 15 31-46

[10] Indrawaty and Wardayati SM 2016 Implementing Islamic Corporate Governance (ICG) And Islamic Social Reporting (ISR) In Islmic Financial Institution (IFI), Procedia Social Behaviour Science. 219 338-343

[11] Darus F, Shukri NH, Yusoff H, Ramli A, Zain MM, and Abu NAB 2017 Empowering Social Responsibility of Islamic Organizations through Waqf, Res. Int. Bus. Financ. 42 959-965

[12] Arshad R, Fatah MMA, and Othman R 2014 Board Composition, Islamic Corporate Social Responsibility and Corporate Reputation of Islamic Banks, in Proceedings of World Business and Economics Research Conference (New Zealand: Auckland) ISBN: 978-1-922069-45-0.

[13] Lestari P 2013 Determinants Of Islamic Social Reporting In Syariah Banks : Case Of Indonesia, Int. J. Bus. Manag. Invent. 2 28-34

[14] Ratri RF and Dewi M 2017 The Effect of Financial Performance and Environmental Performance on Firm Value with Islamic Social Reporting ( ISR ) Disclosure as Intervening Variable in Companies Listed at Jakarta Islamic Index ( JII ), in SHS Web of Conferences. 34 1-6

[15] Othman R and Thani AM 2010 Islamic Social Reporting Of Listed Companies In Malaysia, Int. Bus. Econ. Res. J. 9 135-144,.

[16] Rajeh A, Alamer A, Bin Salamon H, Qureshi MI, and Rasli AM 2015 How do We Measure Corporate Social Responsibility of Islamic Banks through their Business Processes and Oriented Outcomes?, Int. J. Econ. Finance. 5 190-197

[17] Kamla R and Husssain Rammal G 2010 Social Reporting By Islamic Banks: Dose Social Justice Matter?. 1-23

[18] Undang-Undang Nomor 5 tahun 1984 tentang Perindustrian

[19] Undang-Undang Republik Indonesia Nomor 33 Tahun 2014 Tentang Jaminan Produk Halal 
[20] Baydoun N and Willett R 2000 Islamic corporate reports, Abacus. 36 71-90

[21] Syahiza A, Roshima S, Haslinda Y, Yusuf HO, and Rahayati A 2014 The Relationship between Islamic Corporate Social Responsibility and Firm 's Performance: Empirical Evidence from Shari' ah Compliant Companies, Eur. J. Bus. Manag. 6 161-174

[22] Deegan C, Rankin M, and Voght P 2000 Firms' Disclosure Reactions to Major Social Incidents: Australian Evidence, Account. Forum. 24 101-130

[23] Elasrag H 2015 Corporate social responsibility: An Islamic Perspective perspective, https://mpra.ub.uni-muenchen.de/67537 